“SHAKIN" UP” RACE AND GENDER 


\section{Chicana Matters Series}

DEENA J. GONZÁLEZ AND ANTONIA CASTAÑEDA, EDITORS

Chicana Matters Series focuses on one of the largest population groups in the United States today, documenting the lives, values, philosophies, and artistry of contemporary Chicanas. Books in this series may be richly diverse, reflecting the experiences of Chicanas themselves, and incorporating a broad spectrum of topics and fields of inquiry. Cumulatively, the books represent the leading knowledge and scholarship in a significant and growing field of research and, along with the literary works, art, and activism of Chicanas, underscore their significance in the history and culture of the United States. 


\section{“Shakin' Up" Race and Gender INTERCULTURAL CONNECTIONS IN PUERTO RICAN, AFRICAN AMERICAN, AND CHICANO NARRATIVES AND CULTURE (1965-1995)}

Marta E. Sánchez 
Illustrations in this work are by David Avalos, Professor of Visual Arts, California State University San Marcos

Copyright (C) 2005 by the University of Texas Press

All rights reserved

Printed in the United States of America

First edition, 2005

Requests for permission to reproduce material from this work should be sent to:

Permissions

University of Texas Press

P.O. Box 7819

Austin, TX 78713-7819

www.utexas.edu/utpress/about/bpermission.html

(0) The paper used in this book meets the minimum requirements of ANSI/NISO Z39.48-1992 (R1997) (Permanence of Paper).

Library of Congress Cataloging-in-Publication Data

Sánchez, Marta Ester.

"Shakin' up" race and gender : intercultural connections in Puerto Rican, African American, and Chicano narratives and culture (1965-1995) / Marta E. Sánchez. — 1st ed.

p. $\quad \mathrm{cm} .-$ (Chicana matters series)

Includes bibliographical references and index.

ISBN 0-292-70693-6 (cl. : alk. paper) — ISBN 0-292-70965-X (pbk. : alk. paper)

1. American literature-Minority authors-History and criticism. 2. American literature - 2oth century-History and criticism. 3. Puerto Ricans - United States - Intellectual life.

4. African Americans - Intellectual life. 5. Mexican AmericansIntellectual life. 6. African Americans in literature. 7. Mexican Americans in literature. 8. Puerto Ricans in literature. 9. Ethnic groups in literature. 10. Minorities in literature. 11. Sex role in literature. 12. Narration (Rhetoric) 13. Race in literature. I. Title: "Shakin' up" race and gender. II. Title. III. Series. PS153.M56s26 2005

$810.9^{\prime} 920693^{\prime} 09045$ - dc22 
For my students 
THIS PAGE INTENTIONALLY LEFT BLANK 